症例

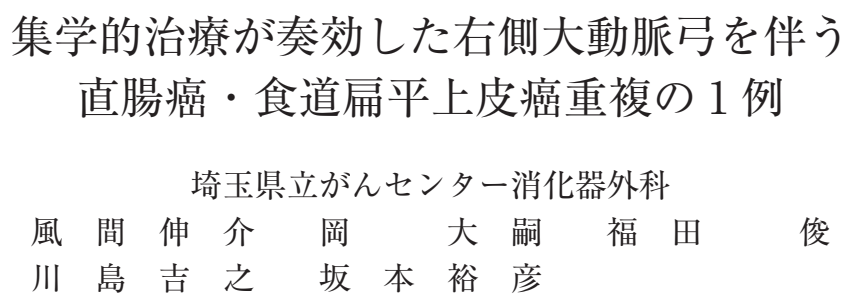

症例は77歳の男性で，排便困難と排便時出血を主訴に近医を受診した。下部消化管内 視鏡検查にて直腸 $(\mathrm{RSa})$ に全周性病変, 上部消化管内視鏡検查で中部食道に 1 型病変 を認め, 直腸・食道重複癌の診断で当院紹介受診した。直腸癌はcT3, cN0, cM0, Stage II，食道癌はcT2，cN0，cM0， Stage II の診断で，胸部CT検查で左鎖骨下動脈 起始部異常を伴う右側大動脈弓を認めた。キャンサーボードで検討した結果, 進行直腸 癌に対し根治手術, 続いて食道癌に対し根治的化学放射線療法 (CRT) を施行する方 針とした．直腸癌はpT3, pN1, pStage IIIaであり, 続くCRTでは化学療法をmFOLFOX6 療法として施行. 現在, 直腸癌は 1 年 4 力月無再発, 食道癌は $\mathrm{CRT}$ 後 $\mathrm{CR}$ を維持 している. 進行直腸癌に進行食道癌を重複し, さらには稀な解剖学的異常を有する高龃 男性に, 集学的加療が奏効した 1 例を報告する.

索引用語：食道扁平上皮癌, 右側大動脈弓, 直腸癌

緒言

食道癌は, 他臓器癌と重複することも多く, その治 療方針の決定には患者の病状, 耐術能, 解剖学的特徴 などから難渋することも多い. 今回われわれは, 進行 直腸癌の精査中に食道癌が偶然発見され, しかも右側 大動脈弓という稀な解剖学的異常を伴っていた ${ }^{12)}$ 高 齢男性についてキャンサーボードで治療方針を検討 し, 集学的加療の奏効した 1 例を経験したので文献的 報告を加えて報告する.

\section{症例}

症例 : 77歳, 男性.

主訴：排便困難.

既往歴 : 第四頸椎骨折, 腰椎椎間板ヘルニア, 高血. 圧症.

生活歴：飲酒ビール 2 本/日 $\times 55$ 年間, 契煙30本/ 日 $\times 24$ 年間.

現病歴： 3 年前より便鮮血陽性を指摘されるも放置 していた。 1 年前より排便困難感, 半年前より排便時

2018年 5 月 8 日受付 2018 年 6 月 1 日採用

〈所属施設住所〉

干362-0806 埼玉県北足立郡伊奈町大字小室780
出血を認め，近医を受診、下部消化管内視鏡検査を施 行したところ，直腸（RSa）に全周性の狭窄を認め, 生検の結果高分化型腺癌であった。手術目的に前医を 受診し，スクリーニングの上部消化管内視鏡検査を施 行したところ，食道癌を指摘されて，加療目的に当院 紹介となった。

来院時現症：身長 $159 \mathrm{~cm}$, 体重 $68 \mathrm{~kg}$, BMI 26.67, 1 年で約 $10 \mathrm{~kg}$ の体重減少あり。つかえ，临下困難感 なし、腹部は平坦，軟で圧痛なし，直腸診では腫瘍を 触知しない.

血液検査所見 : 赤血球数 $435 \times 10^{4} / \mu 1$, へモグロビ ン $12.3 \mathrm{~g} / \mathrm{dl}$, ヘマトクリット $38.0 \%$ と軽度の貧血を認 めた。 また腫瘍マーカーは, CEA 3.5ng/ml, CA19-9 $<2 \mathrm{U} / \mathrm{ml}$, 抗 $\mathrm{p} 53$ 抗体 $<0.70 \mathrm{U} / \mathrm{ml}$, SCC $0.8 \mathrm{ng} / \mathrm{ml}$ と いずれも正常範囲内であった。

胸部 $\mathrm{X}$ 線検査：右大動脈弓，右下行大動脈を認め, 左第一弓の欠損を認めた（Fig. 1).

注腸造影：直腸 RSaに長径8.5cm にわたる apple core signを認めた（Fig. 2).

下部消化管内視鏡検査：AVより $10 \mathrm{~cm}$ の直腸に腫 瘍の下縁を有する全周性 2 型病変を認めた。腫瘍の長 径は $8 \mathrm{~cm}$ にわたり, かろうじてファイバーは通過し 


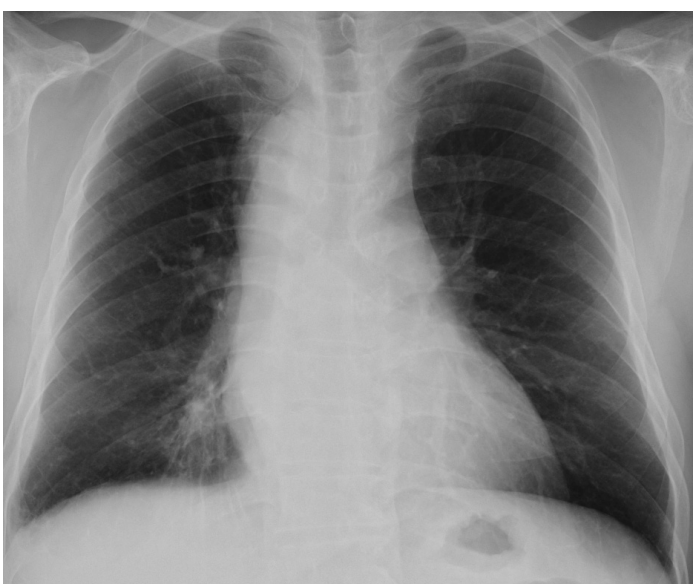

Fig. 1 胸部 X線検査 : 左第一弓の欠損を認める.

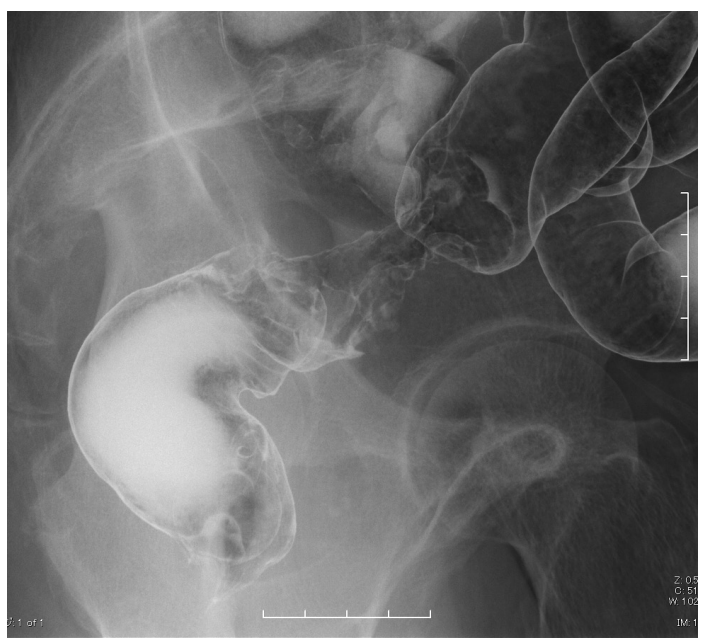

Fig. 2 注腸造影：直腸に長径 $8.5 \mathrm{~cm}$ にわたる apple core signを認める。

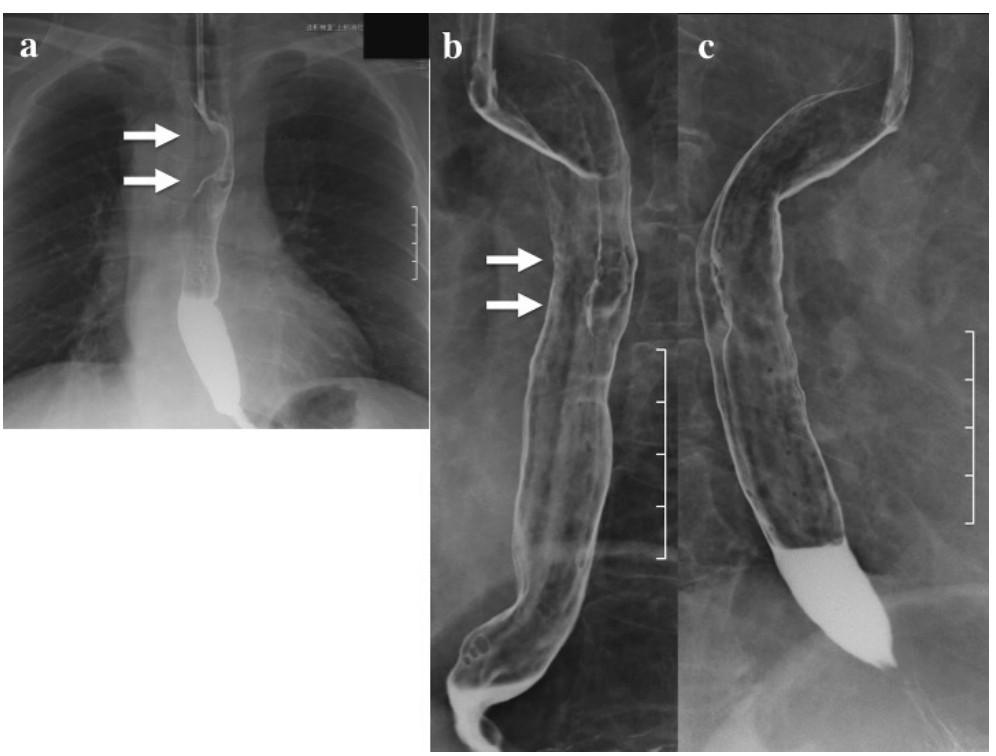

Fig. 3 食道造影：（a ）中部食道は右側大動脈弓と Kommerell憩室による高度な 圧排を認める。（b ）中部食道に隆起性病変を認める。（c）側面像で弧状変形 を認める。

た．当院生検でも高分化型腺癌であった．

食道造影：右側大動脈弓とKommerell㮩室により， 切歯20-25cmの中部食道は高度な圧排を認めた（Fig. 3a). 食道 $(\mathrm{Mt})$ に $18 \times 13 \mathrm{~mm}$ 大の隆起性病変を認め (Fig. 3b)，側面像で弧状変形を認めた（Fig. 3c）。

上部消化管内視鏡検査 : 切歯より $28 \mathrm{~cm}$ の中部食道 右壁に, $20 \mathrm{~mm}$ 大の 1 型病変を認め (Fig. $4 \mathrm{a})$, 生検
で低分化型扁平上皮癌であった.

超音波内視鏡検査 : 右側大動脈弓に伴う高度な圧排 で, 描出不十分であったが, 主病変の深達度はcT2で, 有意なリンパ節の腫大を認めなかった（Fig. 5).

胸腹部 CT 検査 : 中部食道に壁肥厚を認めた. No.106 recR，No.107に転移リンパ節とは確定できない程度 のリンパ節腫大を認めた，直腸 RSaに全周性の壁肥厚 


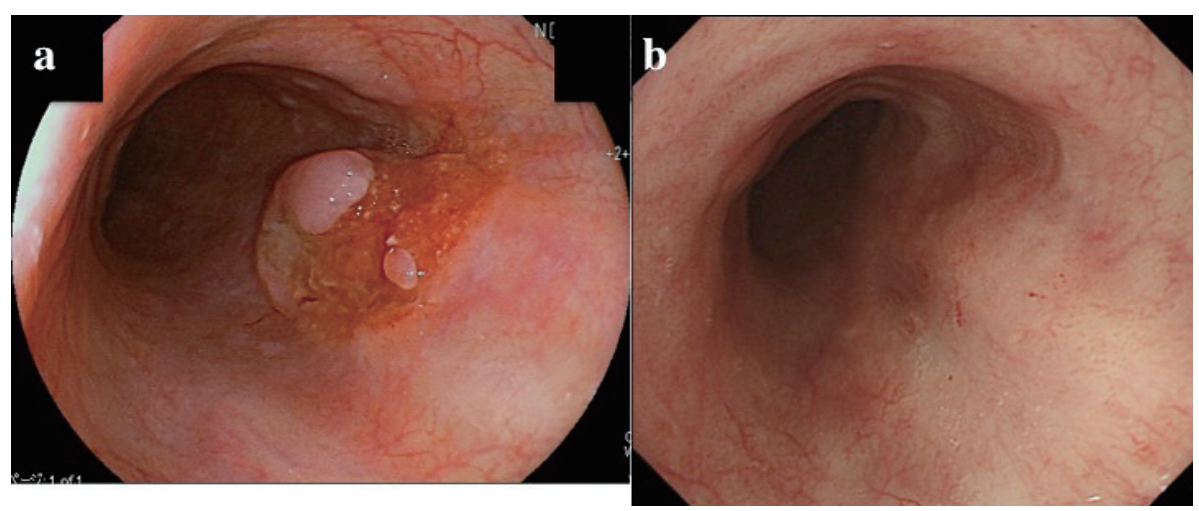

Fig. 4 上部消化管内視鏡検査：（a ）治療前. 切歯上り $20 \mathrm{~cm}$ の中部食道右壁に, $20 \mathrm{~mm}$ 大の 1 型 病変を認める。（b ）治療後．隆起部分は消失し，潰瘍疲痕のみ残存する.

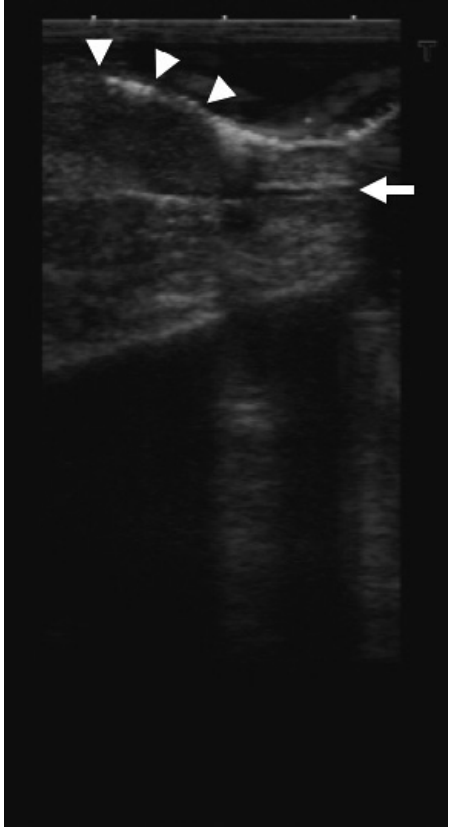

Fig. 5 超音波内視鏡検査 : 腫瘍 (矢 頭）の固有筋層（矢印）への浸潤 を疑う。

を認め, No.251に転移リンパ節とは確定できない程度 のリンパ節腫大を数個認めた. 左鎖骨下動脈起始部異 常を伴う右側大動脈弓とKommerell憩室を認めた (Fig. 6).

以上ょり, 直腸癌 $\mathrm{RSa}, 2$ 型, cT3, $\mathrm{cN} 0, \mathrm{cM} 0$, Stage II, 食道癌 Mt, 1 型, cT2, cN0, cM0, Stage II, Edwards IIIB型の右側大動脈弓と診断した。治 療方針決定に難渋したため, キャンサーボードに提示
して方針を決定することとした。まずは早晚狭窄症状 を認める危険性のある直腸癌の根治手術を先行し, 術 後に食道癌の加療を行う方針とした。また，食道癌に 対する加療としては, 外科切除の方針も検討されたが, 高齢であること, 直腸癌術後となること, 解剖学的異 常を伴うことから根治的化学放射線療法 (CRT) の 方針とし，直腸癌の術後再検討することとした．

手術所見：腹腔鏡下低位前方切除術を施行した。全 身麻酔下で砕石位として，5 ポートで手術を開始した。 腹腔内を観察すると, 腹部に解剖学的異常や左右の乱 れを認めず，明らかな肝転移，腹膜播種を認めず，腫 瘍は直腸 RSaに手拳大の腫瘍として認められたが，漿 膜面への露出は認めなかった。 上方はIMA 根部で結 紮切離して, 同じ高さでLCA・IMVも結禁切離した. 骨盤内は神経温存の層で剥離して, 術中内視鏡で腫瘍 の下縁を確認して，腫瘍下縁より $3 \mathrm{~cm}$ の高さで，洗 浄後にEchelon 60mm Gold (Ethicon社) 1 回で切離 した. 吻合はECS $29 \mathrm{~mm}$ (Ethicon社) を用いて端々 吻合とした。手術時間は 7 時間 7 分，出血量は $68 \mathrm{ml}$ であった。

術後経過：経過は良好で術後 4 病日より食事を開始 し, 術後10病日で退院した。

病理組織学的検査所見：病変は $90 \times 50 \mathrm{~mm}$ の全周性 2 型病変で, 組織型は tub2 > tub1, 深達度はpSS, リンパ節はNo. 251に一つ転移を認め（合計 $1 / 27 ）$, pT3, pN1, pStage IIIaであった.

術後再度キャンサーボードで検討し, 術前の方針通 り食道癌に対する加療はCRTの方針とした。照射野 は術前 CTを参考にして, $42 \mathrm{~Gy}$ までは反回神経リン 


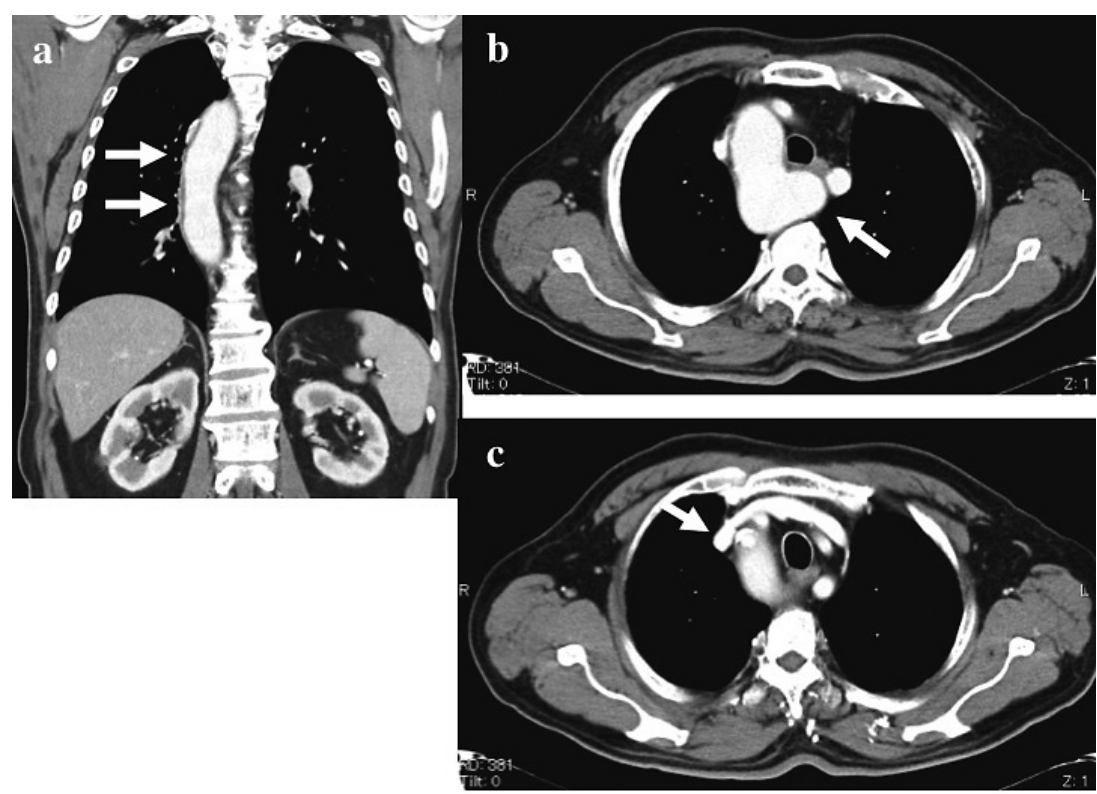

Fig. 6 胸腹部 CT 検查：（a）右側大動脈弓を認める（矢印）。（b ）Kommerell㮩室を認 める (矢印)。（c）左鎖骨下動脈起始部異常を伴う右側大動脈弓を認め, Edwards IIIB 型の右側大動脈弓と診断した.

パ節，および胸部上部食道傍リンパ節から胸部下部食 道傍リンパ節までの予防照射を含めた 4 門照射を, 42Gy 以降は脊䯣を遮蔽し原発と気管分岐リンパ節に 限局した 4 門照射とした。化療とのタイミングについ ては，全身状態も問題ないことから，ガイドライン通 り同時併用とした。さらには直腸癌の最終診断が Stage IIIaであったため, 直腸癌に対する補助化学療法 の目的も兼ね, 化学療法のレジメンを通常の $5 \mathrm{FU}+$ シスプラチンではなく, mFOLFOX6 療法 (levofolinate calcium $200 \mathrm{mg} / \mathrm{m}^{2}$, oxaliplatin $85 \mathrm{mg} / \mathrm{m}^{2}, 5$-fluorouracil : $5 \mathrm{FU} 400 \mathrm{mg} / \mathrm{m}^{2}$ bolus $+1,600 \mathrm{mg} / \mathrm{m}^{2} / 46$ hours，5クールよりbolusなし）とした。中心静脈 ポートを造設した上で, 直腸癌術後46病日より CRT （60Gy，30fr）を開始した。有害事象として，Grade 2 の末梢神経障害, Grade 3 の白血球減少を認めたが, 重篤な有害事象は認めなかった. CRT終了後, 直腸癌 の補助化学療法として, ゼローダ内服 $(2,400 \mathrm{mg}, 2 \times)$ を 3 クール追加した. CRT 終了から 1 力月半後の上 部消化管内視鏡検査では，隆起部分は縮小したものの 残存しており，この時点ではNon-CR/Non-PD と判 断. しかし, 生検では Atypical cellが得られたのみで, CRT 終了から 5 力月後の上部消化管内視鏡検查では CR となった (Fig. 4b). 以後, 外来経過観察されて
おり, 直腸癌術後 1 年 4 力月の時点で無再発生存, 食 道癌も $\mathrm{CRT}$ 後 1 年 1 カ月経過の時点で $\mathrm{CR}$ を維持して いる.

考察

今回われわれは, 高齢男性が進行直腸癌に進行食道 癌を重複し，さらには極めて稀な右側大動脈弓を伴う 症例に際し, キャンサーボードで治療方針を検討し, 集学的加療（直腸癌に対する根治術後に, 直腸癌に対 する補助化学療法も兼ねて mFOLFOX6 療法による 食道癌に対するCRT）を施行し奏効した 1 例を経験 した。

右大動脈弓の頻度は, 本邦では 1,500 人中 $1-2$ 例 ${ }^{1)}$, 欧米の剖検例からの頻度では $0.03 \%-0.04 \%$ とされ

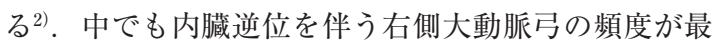
も高く，本症例のように内臟逆位を伴わない右側大動 脈弓の頻度は $0.004 \%$ と極めて稀である. 多くは先天 性心疾患や他の胸膑内の血管異常を合併するとされて いる. Edwardらは，大動脈弓の発生をもとにした重 複大動脈弓の理論模型図を提唱して大動脈弓部の分岐 携带を分類しており ${ }^{344)}$ ，それによると右側大動脈弓 はIII型に分類され, 左鎖骨下動脈の起始部の位置から, $\mathrm{A}$ ：鏡像分岐， B：異常分岐に二分される。本症例は IIIB型であり, III 型が先天性心疾患を伴う頻度は 3 
$-12 \%$ と低く，ほとんどは無症状で偶発的に発見され

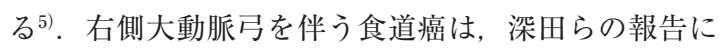
よると, 医学中央雑誌で1983年から2014年の期間で「右 側大動脈弓」「食道癌」, PubMed で1950年から2014年 の期間で「right aortic arch」「esophageal cancer」の 検索から, 自験例も含めて 29 例の報告を認めるのみで あり, 極めて稀である ${ }^{6}$. 食道癌発生に関しては, Edward IIIB型において, 胸部食道が腹側を大動脈弓, 背側を 異常鎖骨下動脈に挟まれて圧排を受けることが関与す ると考察する報告もあるが17), 更なる症例の蓄積か らの考察が必要と考える. 右側大動脈弓を伴う食道癌 の治療に関しては, 報告例はいずれも外科切除が選択 されている. 術式として26例が左側アプローチを選択 しており, うち 4 例は上縦隔郭清のために, 胸骨縦切 開を追加している ${ }^{6)}$. また, 近年では鏡視下手術の報 告も認められる5). しかしながら, これまでの報告の 考察を見ると, 外科手術が施行されてはきたが, 右側 大動脈弓を伴う食道癌に対する外科手術の一番の問題 点は, 反回神経周囲リンパ節郭清, 特に右反回神経周 囲リンパ節の郭清が困難であるということである. 左 反回神経の走行は, 過去の報告では, 詳細不明例を除 き全例で動脈管を反回していた，そのことから郭清に 至る手順として, 左迷走神経を同定して, 左肺動脈, 動脈管索を同定する方法と，動脈管索を同定したあと に, 右側に剥離を進め, 左迷走神経から分岐する左反 回神経を同定する方法とがよく知られている ${ }^{6}$. 左側 アプローチは, こうした左反回神経の走行に基づき, 動脈管周囲の郭清が直視下で安全に行えるという理由 から選択されている. 一方, 右反回神経の走行は, 右 大動脈弓を反回部とする. そのため, 右反回神経周囲 の郭清については, 左側アプローチでは, 右反回神経 が死角に入り困難であるとする報告が多い6).この問 題の解決のため, 胸骨縦切開の追加を推奖する報告も あるが25)8), 過大侵襲を伴うとしてその意義は未だ確 定してはいない. 今回の症例では, 右側大動脈弓を伴 う食道癌にさらに直腸癌を重複していた. 右側大動脈 弓を伴う食道扁平上皮癌に直腸癌を重複した症例の治 療例は，これまでに報告されていない. われわれも右 側大動脈弓を伴う食道癌単独症例に対し, 右上縦隔の 郭清が不十分となる可能性に関しては縦隔鏡を利用し てのリンパ節郭清を伴う手術を考慮したが, 同様の症 例に対する同術式の経験はなかった. 今回の症例では 進行直腸癌を合併しており, 直腸癌は早晚狭窄症状を きたす危険性から, まずは直腸癌の根治手術を施行し,
食道癌に関しては高齢, 直腸癌術後, 解剖学的異常の 合併ということを考慮してCRTを行う方針した。必 要ならばサルベージ手術の追加も考慮していたが, 現 時点で CR と食道癌に関してCRTが奏効した.

食道癌に対する治療方針として，本症例のように Stage II の患者に対する標準的治療は, 術前化学療法 $\left(5 \mathrm{FU}+\right.$ シスプラチン $(\mathrm{FP})\left(80 / 800 \mathrm{mg} / \mathrm{m}^{2}\right): 2$ クール) と外科手術である。この標準的加療の決定には, JCOG において施行された二つの臨床試験の結果が重要な役 割を果たした。臨床病期 II 期および血期胸部食道癌に 対する $5 \mathrm{FU}+$ シスプラチン術前補助化学療法と術後 補助化学療法のランダム化比較試験 (JCOG9907) と, Stage II ・ II 進行食道癌に対する放射線化学療法同時 併用療法の第 II 相臨床試験（JCOG9906）である. JCOG9907試験では, 5 年生存率が, 術前化学療法群 では $55 \%$ で, 術後化学療法群の $43 \%$ に比較して有意に 優れていた 9 . ただし, 本試験は75歳以下が対象とな っており, 高齢者には更なる検討が必要である. 実際, 当院では76歳以上の高齢者に対する補助化学療法の適 応は個別に検討を行っている. またJCOG9906試験で は， CR率は $62.2 \%(46 / 74) ， 5$ 年生存率は $36.8 \%$ であ った ${ }^{10)}$.この試験結果から, CRT 単独では治療効果 が不十分とされたが, 本療法は高齢者, 耐術能のない 患者, 手術を希望しない患者に対する治療の選択肢と しては重要であるとされている。本症例に関しては, 高齢者, 直腸癌術後, 解剖学的異常を考慮して, 食道 癌の加療はCRTの方針とし, 化学療法の薬剤の選択 に関しては, 直腸癌に対する補助化学療法の意味合い も含め, mFOLFOX6 療法を選択した. Conroy らは切 除不能食道癌（扁平上皮癌 $85.8 \%$, 腺癌 $13.9 \%$ ）に対 する，多施設ランダム化第 II / III 相比較試験（FOLF$\mathrm{OX}+\mathrm{RT}$ vs. FP+RT) を行っている. 無増悪生存 期間は, FOLOFOX群9.7カ月, FP群9.4カ月 $(\mathrm{p}=0.64)$, 全生存期間はFOLOFOX群20.2力月, FP群17.5力月 ( $\mathrm{p}=0.70)$ で有意差を認めなかった ${ }^{11)}$. FP療法に比較 して簡便で有用な治療オプションではあるが, 現時点 で本邦ではオキサリプラチンは食道癌に対して保険適 応がない. しかし本症例のように, 大腸癌を重複して いる症例では検討されるべき治療オプションである.

キャンサーボードに関しては, 2008年の厚生労働省 健康局長通知にて, 地域連携拠点病院の要件として, キャンサーボードの開催が要求されたことから全国で 普及し, 当院でも定期的に開催されている. キャンサ ーボードの有用性に関する報告はあまり認められない 
が, Ichikawa ら放射線科医が，キャンサーボードで の治療オプションの選択の実際を報告している ${ }^{12}$. そ れによると, 放射線治療以外の単独治療を予定してい た 148 症例中 2 症例に放射線治療が推奨され, うち 1 症例で施行された．放射線治療を含まない集学的治療 を予定していた 9 症例中 2 症例に放射線治療が推奨さ れ 2 症例に施行されたと報告されている. 本症例でも, 進行直腸癌合併, 高龃, 解剖学的異常を伴う食道癌に 対する治療には, 様々な視点からの検討が重要であり, 今回は食道癌の治療方針の決定, CRTに打ける化学 療法のレジメンの決定, いずれの方針決定にもキャン サーボードでの横断的な検討が有用であった.

\section{結語}

右側大動脈弓を伴う食道癌は, リンパ節郭清を伴う 手術が比較的困難であり, さらに進行直腸癌を合併し た高齢男性の治療について, キャンサーボードで検討 し, 集学的加療の奏効した 1 例を経験した.

利益相反：なし

\section{文献}

1）石黒秀行, 桑原義之, 篠田憲幸他：右側大動脈弓 に合併した食道表在癌の 1 手術例. 日消外会誌 $2011 ; 36: 85-90$

2）天野高行, 鶴丸昌彦, 梶山美明他 : 右大動脈弓を 伴った食道癌手術例. 手術 $2003 ; 57: 1549-1554$

3) Edwards JE : Anomalies of the derivatives of the aortic arch system. Med Clin North Am $1948 ; 32$ : $925-949$

4) Knight L, Edwards JE : Right aortic arch. Types and associated cardiac anomalies. Circulation $1974 ; 50: 1047-1051$

5) Yano M, Shiozaki H, Murata A, et al : Successful resection of thoracic esophageal cancer associated with the right aortic arch. Surg Today 1998; $28: 76-78$

6）深田真宏, 長尾成敏, 仁田豊生他：右側大動脈弓 症例に発生した穿孔性胸部食道癌の 1 例. 日臨外 会誌 $2016 ； 77 ： 1410-1416$

7) 中村英実, 井手博子, 江口礼紀 : 右側大動脈弓に 合併した 0-2 型食道粘膜癌の 1 例. Prog Dig Endosc 消内視鏡の進歩 $1993 ; 42: 169-172$

8）瀬戸口智彦, 神谷欣志, 今野弘之: 右大動脈弓に 合併した食道癌の 1 切除例. 日消外会誌 2009 ； $42: 247-252$

9) Ando N, Kato H, Igaki H, et al : A randomized trial comparing postoperative adjuvant chemotherapy with cisplatin and 5 -fluorouracil versus preoperative chemotherapy for localized advanced squamous cell carcinoma of the thoracic esophagus (JCOG9907). Ann Surg Oncol 2012 ; $19: 68-74$

10) Sasaki $Y$, Kato $K$ : Chemoradiotherapy for esophageal squamous cell cancer. Jpn J Clin Oncol $2016 ; 46: 805-810$

11) Conroy T, Galais MP, Raoul JL, et al : Definitive chemoradiotherapy with FOLFOX versus fluorouracil and cisplatin in patients with oesophageal cancer (PRODIGE5/ACCORD17) : final results of a randomised, phase $2 / 3$ trial. Lancet Oncol $2014 ; 15: 305-314$

12) Ichikawa M, Nemoto K, Miwa M, et al : Status of radiotherapy in a multidisciplinary cancer board. J Radiat Res 2014 ; 55 : 305-308 


\title{
A CASE OF RECTAL AND ESOPHAGEAL CANCER ASSOCIATED WITH THE RIGHT AORTIC ARCH
}

\author{
Shinsuke KAZAMA, Daiji OKA, Takashi FUKUDA, \\ Yoshiyuki KAWASHIMA and Hirohiko SAKAMOTO \\ Department of Gastroenterological Surgery, Saitama Cancer Center
}

A 77-year-old man presented to a local hospital due to dyschezia and bleeding on defecation. Colonofiberscopy revealed a tumor encircling the circumference of the upper rectum (RSa), and gastrointestinal endoscopy detected a protruded tumor in the middle esophagus. Therefore, the patient was referred to our hospital with a diagnosis of double cancer of the rectum and esophagus. The rectal cancer was diagnosed as cT3N0M0, cStage II, and the esophageal cancer, as cT2N0M0, cStage II according to the Japanese Classification. Chest computed tomography showed the right aortic arch with an aberrant left subclavian artery classified as type IIIB aortic arch anomaly based on the Edwards' classification. The patient underwent low anterior resection for the rectal cancer, and chemoradiotherapy for the esophageal cancer. We selected mFOLFOX6 as both chemotherapy for esophageal cancer and adjuvant chemotherapy for rectal cancer. The patient is now alive without recurrence of the diseases over 1 year and 4 months after the operation. In conclusion, we experienced a rare case of successful treatment of rectal and esophageal cancer associated with the right aortic arch, a rare anatomical anomaly. Multimodal therapies including surgery and chemoradiosurgery might be a potent treatment for this patient.

Key words : esophageal cancer, right aortic arch, rectal cancer 